\title{
Colin Haslam*
}

\section{International Financial Reporting Standards (IFRS): Stress Testing in Financialized Reporting Entities}

https://doi.org/10.1515/ael-2017-0016

Published online February 17, 2017

Abstract: These remarks deal with financialisation of accounting. Financialisation is a process by which windfall capital market gains are crystallised from future earnings over and above those available from current earnings and profit. Accounting numbers reported by business firms are increasingly including the product of windfall gains from capital markets into those accounting numbers. Thus a significant disturbance in market valuations embedded in firm's assets and earnings could have a significant and material impact upon firm-level financial stability.

Accounting for the European Private Sector: Reconsidering Accounting Objectives for Economy and Finance

1. “Accounting for Europe's Economy and Society: Considerations for Financial Stability, Economic Development and the Public Good” by Yuri Biondi, https://doi.org/10.1515/ael2017-0018

2. "On the Accounting Regulation for the European Private Sector" by Arnaldo Canziani, https://doi.org/10.1515/ael-2017-0015

3. "The Need to Reform the Dangerous IFRS System of Accounting" by Jacques Richard, https://doi.org/10.1515/ael-2017-0017

4. “International Financial Reporting Standards (IFRS): Stress Testing in Financialized Reporting Entities" by Colin Haslam, https://doi.org/10.1515/ael-2017-0016

5. “Open Debate on Accounting for the European Private Sector” by Imke Graeff, https://doi. org/10.1515/ael-2017-0024

Thank you for inviting me here. I will be discussing a topic around financialisation of accounting, research work that my team and I have been working on for a number of years. But I thought I might start from a quote from the Accounting, Economics and Law journal: Economists consider the current value of a business' enterprise to be measurable by capitalising the expected earnings of that company.

Accountants are rather more conservative in contrast and find that reporting expected earning valuations are less acceptable. The reason is found in an

*Corresponding author: Colin Haslam, Department of Business and Management, Queen Mary University of London, London E1 4NS, UK, E-mail: c.haslam@qmul.ac.uk 
unwillingness to cut loose their thinking and their service from provable objectivity of accounts, caps and statements made in terms of cost actually incurred by this enterprise before the current date (Littleton, 2011).

There is a tension between what the economists want and what the accountants are trying to deliver. And that theme is the argument of my presentation: The tension between these two ambitions. Our research on financialisation is developed in a number of papers and we describe financialisation as a process by which windfall capital market gains are crystallised from future earnings over and above those available from current earnings and profit; that is, capital markets facilitate asset windfall gains from speculative ongoing capitalisations and recapitalisations. The accounting numbers reported by firms are increasingly including the product of windfall gains from capital markets into the accounting numbers.

The IASB disclosure project has traditionally been focused on providing decision useful information to investors. Prudence however has been replaced with neutrality and relevance for a true and fair view, diluting the commitment to capital maintenance. There is a sort of ebbing and flowing going on here in terms of commitment to core accounting principles. But this change in orientation towards fair value reporting has the potential - we argue - to create dysfunctional economic and social consequences. The change in orientation towards fair value reporting away from historic costs is seen as of benefit to investors who are seeking relevant information, disclosures from firms and their financial statements. The general argument is that fair value reflects fundamental performance of the reporting entity: It provides information to investors which will reduce risk and lower the cost of capital and promotes capital market efficiency because investors are now informed about the risk embodied in their capital allocations.

So on the one hand, accountants have tried to remain prudent and conservative. But, the change to fair value reporting is supported by economists, investors and the IASB because these disclosures promote capital market efficiency. An alternative argument grounded in accounting relies on understanding the system of double entry book keeping which is an information system that transmits financial disturbance between line items within and across financial statements. The problem is that these line items have variable capacity to absorb disturbances and impacts. So an impact that is relatively immaterial to one line item can become a material adjustment to another line item elsewhere in firms' financial statements. Financial disturbance in the current period is now being amplified because asset values are being detemporalised to include past, present and future values in the asset value structure.

Our main argument is that the accounting system can both transmit and amplify disturbances. So in financialised accounts, market values are absorbed into corporate balance sheets capitalisation and because these are essentially speculative 
valuations, a firm's capitalisation runs ahead of earning. The assets values that are being recorded on a firm's balance sheet include speculative assumptions about future earnings and windfalls that have yet to be realised (Haslam, et al., 2016).

For example in the S\&P 500 group of firms since 2000 and since the introduction of fair value reporting, balance sheet values have moved ahead of earnings capacity whether that is profit or cash. So the cash return on capital employed is down from $26 \%$ to below $17 \%$ in 2015 . Balance sheets now absorb and reflect speculative values and capital market conditions. There is an issue here, which is that secondary capital markets are about promoting vendability that is the price at which assets are trading. However, it is often the case that these prices become decoupled from the underlying serviceability of those assets in terms of their earnings capacity.

For example goodwill, which arises out of accounting for the difference between the book and market value of a business combination, is accumulated on the balance sheet rather than depreciated/amortised. Under current accounting regulations goodwill is now tested to see if it is impaired and has to be written down. This goodwill is accumulating ahead of shareholder's equity and retained earnings reserves. Why is that? Because the shareholder's equity line item is on a different trajectory because of increased dividends and share buybacks. So we have goodwill on one side, the asset side, inflating at a faster rate than retained earnings held in shareholder's funds.

In the FTSEurofirst300 group in 2014 some $28 \%$ of firms surveyed reported intangible assets (including goodwill) with a value that exceeded shareholder's equity compared to $17 \%$ of firms in the year 2000. Thus asset impairment (to reported goodwill) could have material and damaging effects on shareholder's funds undermining solvency and viability.

Consider the case of Tesco - just a couple of weeks ago - where a property re-evaluation wiped out $50 \%$ of the shareholder's fund and converted a favourable debt/liquidity ratio into a very unfavourable damaging the credit rating.

The legal and moral foundation of nineteenth century limited liability was grounded on a general principle of reciprocity. Governments granted loss limits for investors on the understanding that they would put something back: Investing in infrastructure for economic growth and a wider contribution to social welfare. This reciprocity has been undermined because the speculative actions of shareholder/ investors are no longer isolated from the assets and liabilities of the firm. In the financialised firm investor interests are being privileged against the interests of other stakeholders in the organisation and contrary to the reciprocity of limited liability.

So adverse financial disturbances generated by changes in market values (or judgements about market value) will be transmitted across the financial statements and line items may or may not have the capacity to absorb these financial impacts. This is going to translate into a real moral hazard for society going 
forward, because broader stakeholder's settlements will be undermined as investors try to protect their positions.

Our research is not about whether one system of accounting (historic costs or market value accounting) is good or bad but employ evidence based research to inform and anticipate unintended consequences. That is, if we have one message for the IASB, it is that market value accounting absorbs speculative capital market conditions into firm financial statements. Our analysis suggests that market values recorded intangible assets are accumulating ahead of shareholder's equity, which acts as a buffer against insolvency. Thus a significant disturbance in market valuations embedded in firm's assets could have a significant and material impact upon firm-level financial stability.

Acknowledgements: This article was prepared for and read at the international workshop on "Which accounting regulation for Europe's economy and society?" organised under the auspices of the European Parliament in Strasbourg, on 20 May 2015, in tribute to Mr Jérôme Haas (1963-2014), first chairman of the Accounting Standards Authority of France (ANC). It was organised by the Laboratory of Excellence on Financial Regulation (Labex ReFi), which is supported by PRES heSam under the reference ANR-10-LABX-0095. It benefitted from a French government grant by the National Research Agency (ANR) under the funding program 'Investissements d'Avenir Paris Nouveaux Mondes (Investments for the future Paris - New Worlds) reference ANR-11-IDEX-0006-02.

Funding: Labex ReFi/PRES heSam, (Grant/Award Number: 'ANR-10-LABX-0095') 'Investissements d'Avenir Paris Nouveaux Mondes (Investments for the future Paris - New Worlds), (Grant/Award Number: 'ANR-11-IDEX-0006-02').

\section{References}

Littleton, A. C. (2011). Economists and Accountants. Accounting, Economics, and Law: A convivium, 1(2).

Haslam, C., N. Tsitsianis, R. Hionaru, T. Andersson \& G. Katechos. (2016). Stress Testing International Financial Reporting Standards (IFRS): Accounting for Stability and the Public Good in a Financialized World. Accounting, Economics and Law, 6(2). 